\title{
ASSESSING THE PROVENANCE OF CONSTANTINUS AFRICANUS' VENERABILIS ANATOMIA IN LONDON, WELLCOME LIBRARY, MS WELLCOME 290 (FF. 1R-41V) ${ }^{1}$
}

\author{
Jesús Romero Barranco, Universidad de Málaga² \\ Email: jromer@uma.es
}

\begin{abstract}
The present paper analyses the dialectal provenance of the Middle English version of Constantinus Africanus' Venerabilis Anatomia (MS Wellcome 290, ff. 1r-41v). The methodology followed is based on the model supplied by the Linguistic Atlas of Late Mediaeval English (McIntosh et al. 1986). For the purpose, a lemma-based list of the allographs in the manuscript has been used as the input for the LALME questionnaires. In addition, a linguistic analysis of the text corroborates the results obtained in the dialectal study.
\end{abstract}

Keywords: Historical Linguistics, Middle English, dialectology, synchrony, morphology, Constantinus Africanus, anatomy.

Título en español: "Sobre la procedencia de Venerabilis Anatomia de Constantino el Africano, en Wellcome Library, MS Wellcome 290 (ff.1r-41v)"

Resumen: El presente estudio analiza los rasgos dialectales de la versión en lengua vernácula inglesa tardo-medieval del tratado Venerabilis Anatomia, de Constantino el Africano, alojado en Londres, Wellcome Library, MS Wellcome 290 (ff. 1r-41v). De acuerdo con la metodologóa propuesta en A Linguistic Atlas of Late Medieval English (McIntosh et al. 1986), una lista de lemas, con sus respectivos alógrafos, ha servido como punto de partida para el análisis de las variantes ortográficas de naturaleza dialectal. Un análisis lingüístico del texto corrobora la adscripción dialectal propuesta.

Palabras clave: Lingüística Histórica, inglés medio, dialectología, sincronía, morfología, Constantino el africano, anatomía.

\footnotetext{
$1 \quad$ Date of reception: 3 February 2015

Date of acceptance: 4 June 2015

2 The present research has been funded by the Autonomous Government of Andalusia (research project HUM-7597). This grant is hereby gratefully acknowledged. I would also like to thank Dr. Javier Calle-Martín (Dept. of English, University of Málaga) for his valuable comments on the previous drafts of this paper and his support all the way through the completion of it.
} 


\section{INTRODUCTION}

Middle English could be defined as a transitional stage in the history of English, right between "English as a typologically 'Old Germanic' language and English of the type now familiar to us" (Lass 1992: 23). Furthermore, "it exhibits by far the greatest diversity in written language of any period before or since", where "variability was very wide-ranging at every linguistic level: spelling, morphology, syntax and lexicon" (McIntosh 1989a: 7-8; see also Baugh 1959: 189; Milroy 1992: 156; Smith 1999: 121). This diversity was represented by the so-called Middle English dialects ${ }^{3}$ which co-occurred in England during the period between c. 1100 and 1500 . These pieces of written language come to the contemporary linguist through the manuscripts written in the period, which covered a wide range of categories, such as scientific writing, literature or legal proceedings, among others. Of all the categories, scientific writing could be highlighted, as it offers a more natural representation of language, far from the usually ornamented literary or legal language. Apart from the vernacular texts which may have served the ordinary layman, there were others which were made for the use of professional physicians, among which versions of Hippocrates or Galen can be found (Talbot 1967: 191).

Scientific texts started to appear in a larger scale in English during the period covering the fourteenth and fifteenth centuries, thus turning knowledge into something available for a wider readership (Pahta and Taavitsainen 2004: 1-2). ${ }^{4}$ In the labour of copying exemplars into the vernacular, scribes and copyists could adopt three different strategies, which would directly influence today's portrait of Middle English: 1) they could leave the language more or less unchanged, something which rarely happened; 2) they may convert it into their own kind of language by making numerous modifications at the level of ortography, morphology and vocabulary; and 3) they would do something at some point between the two previous alternatives, turning then the translation into a sort of Mischsprache (McIntosh et al. 1986: 13; Esteban-Segura 2010: 258). ${ }^{5}$ As a consequence, different versions of the same exemplar would present different language features depending on the area in which they were copied, as well as the dialectal provenance of the scribe who made it. ${ }^{6}$ Thus, it is the aim of the present paper to take into account the diatopic plane of language, that is, the variation of language across space. ${ }^{7}$ From a historical viewpoint, three major approaches have been made to Middle English dialectology.

\footnotetext{
3 Mossé (1952: 2) terms them Kentish dialect (South-East), Southern dialect (South-West), East Midlands dialect, West Midlands dialect and Northern dialect.

4 The use of English in professional writing can be traced back to the late fourteenth century, when it gradually appeared as the language of legal proceedings, guild records, religious controversy, and instruction (Pahta and Taavitsainen 2004: 10).

$5 \quad$ Laing also labels them 'Literatims', 'Translators' and 'Mixers', respectively (2004: 52).

6 The absence of a nationally recognized standard of written English in the period unfortunately presents readers of Middle English literature with problems of linguistic diversity much greater than those encountered in the reading of post-medieval texts - or indeed Old English ones (Burrow and Turville-Petre 1996: 5).

7 The aim of dialectology is to take into account three analytical planes of language: a) how linguistic forms change through time (diachronic); b) how they vary accross space (diatopic); and c) how the interactions of the speakers and writers of the language produce and define this variation (diastratic) (Laing 2004: 49).
} 
Oakden (1930) covered a period of 300 years (1180-1486), although he concentrated mainly on the 14th century. He studied forty-five items on the basis of literary texts, a few local documents and place names. This study presented two shortcomings: first, diatopic and diachronic variation are confused due to such a wide chronological span; second, the original material is not made available for the reader so that the verification of some data proves impossible (Fisiak 1983: 200; McIntosh 1989b: 22-27).

Some years later, Moore, Meech and Whitehall (1935) used 309 literary texts and documents covering the period $1200-1460$, focusing mainly on the 15 th century. ${ }^{8}$ They studied just eleven items so that it could be said that this project and that by Oakden shared the same problems: a small number of items and a wide chronological spread (Fisiak 1983: 200; McIntosh 1989b: 22-27).

The Linguistic Atlas of Late Middle English, LALME for short, (McIntosh et al. 1986) covers the period 1350-1450 and it is exclusively oriented towards written English. Out of a total of $1150 \mathrm{MSS}$, the number of studied items amounts to 270. As for the typology of texts, both literary texts and local documents have been included (Fisiak 1983: 201; McIntosh 1989b: 22-27). When it comes to English historical dialectology, Middle English in particular, $L A L M E$ is now elsewhere deemed the perfect tool to ascertain the likely provenance of a given text. As Samuels describes it,

The largest single contribution of this survey [LALME] to the history of English is that it provides us with a frame of reference for isolating and classifying those types of language that are less obviously dialectal, and can thus cast light on the probable sources of the written standard English that appears in the fifteenth century (1989: 66).

However, it needs to be noted that, for many academics, $L A L M E$ is definitely not a reliable source for Middle English dialectology, and that is the reason why linguistic analyses become of paramount importance in studies of this nature. The arguments offered by scholars range from the unclear dialectal boundaries in the atlas (Calle-Martín and Moreno-Olalla 2008: 24) ${ }^{9}$ to the systematic ascription of texts to the county of Essex, as its language constituted "a perfectly acceptable mode for professional London writing in the fifteenth century" (Hanna 2005: 28).

The present paper has been conceived with the following objectives: first, the dialectal provenance of MS Wellcome 290 (ff. 1r-41v) will be stated, employing LALME's methodology; second, a linguistic analysis will be carried out in order to justify the results obtained using the atlas. Thus, the second section presents the methodology that has been employed in order to determine the likely provenance of MS Wellcome $290(\mathrm{ff} .1 \mathrm{r}-41 \mathrm{v})$, henceforth W290; third, the text under examination will be presented and a brief codicological and palaeographic description will be provided; the fourth section will offer the dialectal analysis, following the LALME methodology (McIntosh et al. 1986); the fifth section will

22 literary texts out of 44, and 240 non-literary documents out of 266 are from the time after 1400 (Fisiak 1983: 200).

9 "The isoglosses separating neighbouring counties are sometimes fuzzy, and this worsens if the ascription of an anchor text to a particular county is uncertain" (Calle-Martín and Moreno-Olalla 2008: 24). 
support and corroborate the results obtained in section four through a linguistic analysis. Some conclusions close the paper.

\section{METHODOLOGY}

From a methodological standpoint, the first step was the transcription of the witness under study. For the purpose, the principles of a semi-diplomatic transcription were adopted with the aim of offering an edition as faithful as possible to the original. Therefore, features such as spelling, punctuation and emmendations were accurately reproduced, and abbreviations expanded in italics, thus providing the linguist with a reliable source for research purposes which contributes not only to Linguistics, but also to Codicology, Palaeography or Ecdotics, among others.

The next stage was the tagging and lemmatization of the corpus. Following the rationale of the Málaga Corpus of Late Middle English Scientific Prose, W290 ${ }^{10}$ was tagged so as to contain the lemma, word-class, accidence and meaning of every running word in the text.

\begin{tabular}{|c|c|c|c|c|c|c|c|c|c|}
\hline ID & Word & Lemma & Category & $\begin{array}{c}\text { Sub- } \\
\text { category }\end{array}$ & Type & Tense & Num. & Pers. & Fol. \\
\hline 27 & Sothly & sōthlī, b & Adve & Manner & & & & & $1 \mathrm{r}$ \\
\hline 28 & pe & thē, $\mathrm{d}$ & Dete & Artic & & & & & $1 \mathrm{r}$ \\
\hline 29 & brayn & brain, $\mathrm{n}$ & Noun & & & & Sing & & $1 \mathrm{r}$ \\
\hline 30 & ys & bēn, va & Verb & & Anom & PrsInd & Sing & 3 rd & $1 \mathrm{r}$ \\
\hline 31 & soyft & soft, a & Adje & & & & & & $1 \mathrm{r}$ \\
\hline 32 & yn & in, $\mathrm{p}$ & Prep & & & & & & $1 \mathrm{r}$ \\
\hline 33 & hys & his, $\mathrm{d}$ & Dete & Poss & & & Sing & $3 \mathrm{rd}$ & $1 \mathrm{r}$ \\
\hline 34 & substance & substaunce, $\mathrm{n}$ & Noun & & & & Sing & & $1 \mathrm{r}$ \\
\hline
\end{tabular}

Table 1. Tagging system (sample)

Table 1 above displays the tagging and lemmatization for every single word or punctuation mark in W290. In this manner, each item is tagged in terms of lemma, category, sub-category, type, tense, number, person, folio and meaning. For the sake of accuracy, the lemmas correspond to those recorded in the Middle English Dictionary (Kurath et al. 1956-2001). Apart from the corpus itself, corpus design allows for the automatic generation of a glossary that may be offered as a tool-kit for an efficient reading of the text.

10 This text forms part of the collection of The Málaga Corpus of Late Middle English Scientific Prose (http:// hunter.uma.es), whose main objectives are a) the digitisation and diplomatic transcription of late Middle English hitherto unedited scientific treatises; and b) the compilation of an annotated corpus which may be used as the input for linguistic research. It is the result of a research project developed at the university of Málaga in collaboration with the universities of Jaén, Glasgow, Murcia and Oviedo. (Calle-Martín and Miranda-García 2011: 3-20). For a more detailed description of the corpus, see Calle-Martín and Moreno-Olalla (2008: 18-20). 


\begin{tabular}{|c|c|}
\hline $\mathbf{U}$ & V \\
\hline $\begin{array}{l}\text { uncurable, } a \text {. Not amenable to medical } \\
\text { treatment, incurable } \\
\text { vncurable }(1 \mathrm{x}) \\
\text { under, } p \text {. Under } \\
\text { vnder }(14 \mathrm{x}) \text {, vnder }(12 \mathrm{x}), \text { Under } \\
(2 \mathrm{x}), \\
\text { vndyr }(1 \mathrm{x}) \\
\text { until, } b \text {. Until } \\
\text { tyl }(2 \mathrm{x}), \text { tyll }(1 \mathrm{x})\end{array}$ & 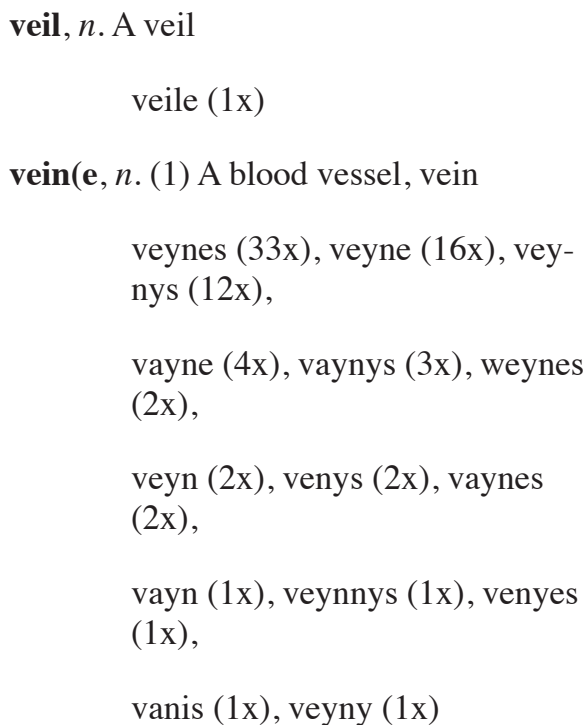 \\
\hline
\end{tabular}

Table 2. Sample glossary

Table 2 shows a sample glossary of the words in W290 and, as can be easily observed, it offers the reader quite relevant information, such as category and meaning together with the different allomorphs with their frequency in the text.

Finally, the tool Text Search Engine (Miranda-García and Garrido-Garrido 2013) is used to automatically generate a lemma-based list of allographs, which are later taken as the input for the $L A L M E$ questionnaires, according to the 'fit-technique'. First, the questionnaire is filled in by taking some of the words in the text, mainly functional words; secondly, these items are placed in the dot maps, thus providing a likely area of composition for that text; next, the results will be checked against the item maps, which afford a more specific localisation of the variants of a word. Finally, the county dictionary confirms a likely provenance for the text in the light of other items which have not been previously dotted in the item maps (Benskin 1991: 24).

\section{THE TEXT}

W290 is housed in the Wellcome Library, London. Referenced MS Wellcome 290, it is entitled Pseudo-Galen, Claudius, 131 - 201, and it comprises 56 folios of which the last three are blank (Moorat 1962: 186). The volume is divided into two treatises: a) Constantinus Africanus Venerabilis' Anatomia (ff. 1r-41v); and b) Galen's Anatomy (ff. 42r-56v). In the first part of the volume, Constantinus Africanus makes a description of important aspects of the human body, giving laymen some advice. 
Of anonymous authorship, this Middle English copy is written in vellum and the binding is also found to be done in the same material. Concerning the state and preservation of this witness, it can be safely said that it is in overall good condition, although some damage can be observed on the margins, which are slightly cropped. The dimensions of the volume are $18 \times 13 \mathrm{~cm}$. As for the ink, the text is written in two main colours, brown and red, the former used for the body of the manuscript while the latter is preferred for the headings and the endings of the chapters (which are usually written in Latin). The brownish colour used in the body slightly fades after f. 25 , and it is kept in this shade until the end of the volume. Apart from these two main colours, the scribe represents large illuminated initials in gold and colours with feather ornaments on ff. 1r, 29r, 37r and 41v. Paragraph marks are represented in an unusual form, in alternate gold and blue on a red ground. Regarding the ruling, Constantinus Africanus' Venerabilis Anatomia presents both the frame (prolonged to the outer edges) and the lines ruled, suggesting that this witness was plausibly written before the middle of the 15th century ${ }^{11}$ (Moorat 1962: 186).

On palaeographic grounds, the script in W290 combines bastard anglicana hand with some distinctive shapes from the secretary script. Actually, Roberts (2005: 164) and Brown (1990: 100) term this kind of script cursive anglicana formata hybrida and anglicana formata hybrida, respectively. Similar instances of this hand can be found in the manuals on palaeography by Parkes (1969: pls. 7-8), Brown (1990: pl. 37) or Derolez (2003: pls. 84-86).

\section{DIALECTAL ANALYSIS}

In order to generate the linguistic profile of W290, items from the general section of $L A L M E$ were taken and, as their morphology pointed to the east-southern area of the country, items from the southern section of $L A L M E$ were added to the former questionnaire. In table 1 below, part of the linguistic profile of W290 is displayed, providing the allomorphs of each word with their corresponding number of appearances in brackets. In addition, the most frequent variants have been highlighted in bold script.

\begin{tabular}{|l|l|}
\hline after & after (52) I Affter (6) \\
\hline any & eni (1) \\
\hline but & but (23) I butt (1) \\
\hline each & eche (1) \\
\hline flesh & flech (6) I flesch (2) I flessh (1) \\
\hline from & from (55) I fro (16) I frome (3) \\
\hline I & I (1) \\
\hline less & lesse (6) I lasse (1) \\
\hline man & man (6) I mane (2) I mannys (1) \\
\hline
\end{tabular}

11 According to Petti, "in the late 15 th century ruling became less fashionable and only the frame remained, an element which would be omitted in the 16th century" (1977: 6). 


\begin{tabular}{|l|l|}
\hline much & much (2) I moche (1) \\
\hline neither & neyber (1) \\
\hline other & other (13) I oper (8) I oder (1) \\
\hline shall & scholde (4) I schuld (4) \\
\hline than & pan (6) I than (1) I panne (1) I thanne (1) \\
\hline them & pem (4) I them (3) I pem (1) \\
\hline then & pen (1) I pene (1) I thenes (1) \\
\hline they & pei (36) I pey (2) I they (1) \\
\hline until & tyl (1) \\
\hline well & wele (5) I wel (2) I well (1) I welle (1) I weyl (1) \\
\hline when & whan (20) I whane (1) I whanne (1) \\
\hline -ly & aliuelych (1) I clothelych (2) I dedelych (1) I prencypallych (1) \\
\hline
\end{tabular}

Table 3. Linguistic Profile of W290 (partial).

As can be gathered from the table above, items were selected according to two basic principles: the degree to which they display regional variation, and their frequency, so as to work with a questionnaire which may offer enough discrimination to localise the area in which W290 was written (McIntosh et al. 1986: 1-50).

Consequently, 20 items were selected on the basis of the above mentioned criteria. The linguistic profile was limited to the following series of allomorphs: after (after), any (eni), but (but), each (eche), flesh (flech), from (from), I (I), less (lesse), man (man), much (much), neither (neyper), other (other, oper, oder), shall (scholde, schuld), than (pan, than, panne, thanne), them (pem, them, pem), then (pen, pene, thenes), they (pei, pey, they), until (tyl), well (wele, wel, well, welle, weyl), when (whan, whane, whanne) and adverbs in -ly (-lych). In the light of these 20 words, the data obtained led us to conclude that W290 seems to have been written somewhere in the counties of Norfolk, Suffolk, Essex, London and Hertfordshire.

Next, the item maps of $L A L M E$ were employed with the intention of narrowing that area into something more specific. Thus, some other relevant words were plotted in zone 6 of the item maps.

\begin{tabular}{|l|l|}
\hline be & are (2), ar (1) \\
\hline good & gode (1), goode (1) \\
\hline if & yf (4) \\
\hline little & lytyl (10) \\
\hline many & many (4) \\
\hline might & myght (2) \\
\hline
\end{tabular}




\begin{tabular}{|l|l|}
\hline not & not (33) \\
\hline shall, v & schal (6), schalt (4) \\
\hline these, d & pese (41) \\
\hline wh- & $\begin{array}{l}\text { whych (158), whan (20), what (4), where (2), wherfore (4), why } \\
(\mathbf{3})\end{array}$ \\
\hline
\end{tabular}

Table 4. Inventory of words plotted in zone 6 of the item maps (LALME).

The morphology of the words in Table 4 above led us to the conclusion that W290 is likely to have been written somewhere to the north of river Thames in the county of Essex, ${ }^{12}$ near the city of Chelmsford, thus following the conventions of the East Midlands dialect.

\section{LINGUISTIC FEATURES IN W290}

A linguistic analysis is offered in order to support ${ }^{13}$ the previous assumptions. For the purpose, some relevant morphological aspects will be discussed. First, the usage of $\langle p\rangle$ and $<y>$ will be discussed and, afterwards, a morphological description will close the section.

\section{1. The letters $\langle\mathrm{p}>$ and $<y>$}

Middle English is defined by its diversity and spelling is definitely not an exception to this. A clear instance of this lack of regularity could be found in the attitude of scribes towards the use of $\langle\mathrm{p}\rangle$ and $\langle\mathrm{y}\rangle$, which were usually confused as a single $\langle\mathrm{y}\rangle$-like symbol. From a scholarly perspective, this was understood as 'the mark of a late scribe' or a 'Norman influence'. However, Benskin (1982: 14) affirms that there are diatopic explanations for this, and he distinguishes three categories of usage among scribes:

(I) $\langle$ p $>$ and $<y>$ are confused as a single symbol, which may be $\langle$ p $>$-like or $<y>$-like in appearance.

(II) $\langle\mathrm{p}\rangle$ and $\langle\mathrm{y}\rangle$ are discretely distinct symbols, and there are no intermediate letter-shapes which defy classification as either $\langle\mathrm{p}\rangle$ or $\langle\mathrm{y}\rangle$, but their functions are confused. Therefore, the exponent of $\langle\mathrm{p}\rangle$ appears sometimes also as the exponent of $\langle\mathrm{y}\rangle$, and vice versa (<wpll $>$ for <will $>$ and $<$ yaim $>$ for 'them', respectively).

(III) $<$ p $>$ and $<$ y $>$ are discretely distinct symbols, there are no intermediate shapes, and they are used in their historically regular functions.

From the three categories explained, type (I) characterizes the writing of scribes from the Northern and some Eastern parts of England, and also from Scotland; type (II), in turn,

\footnotetext{
12 Even though the analysis that has been carried out leads us to state that W290 seems to have been written in the county of Essex, one can never be completely sure whether the scribe was actually a native speaker of that zone or, on the contrary, whether he acquired his habits of written language therein (Benskin 1982: 14; Crespo-García and Lezcano-González 1999: 48).

13 Linguistic analysis may sometimes confirm, sometimes refute, modify, or even confuse textual or historical evidence, but it always adds something to out knowledge of a scribe and his work (Laing 1988: 84).
} 
is confined mainly to the borders between areas of type (I) and areas of type (III); and type (III) is central, Western and South-Eastern Midland and Southern (Benskin 1982: 14).

In the particular case of W290, the scribe that took over the task of copying or translating it adopted type (I) in the usage of $\langle\mathrm{p}\rangle$ and $\langle\mathrm{y}\rangle$, where these two graphs were confused as a single symbol. Consequently, representations such as $<y e i>$ for 'they' or $<y n, y f>$ for 'in, if' are observed throughout the witness, thus corroborating its likely Eastern provenance.

\subsection{Morphology}

\subsubsection{Nouns}

During the transition from Old to late Middle English, the noun inflection had been radically reduced, as case-marking (except for genitive) had vanished and most declension classes had been levelled (Brunner 1970: 45; Lass 1999: 140; Barber et al. 2009: 167). ${ }^{14}$ By the Middle English period, and generalising roughly over all dialects, a massive reduction of noun paradigm types had taken place..$^{15}$ Putting aside minor categories like umlaut and zero plurals, two major declensions took over the noun paradigm (Lass 1992: 111):

\begin{tabular}{|l|c|c|}
\cline { 2 - 3 } \multicolumn{1}{c|}{} & Type A & Type B \\
\hline Sg. Nom. and Acc & $-\varnothing$ & -e \\
\hline Sg. Genitive & -es & -e \\
\hline Sg. Dative & $-\varnothing$ & -e \\
\hline Pural & - (e) s / -is / -ys & -es / -en \\
\hline
\end{tabular}

Table 5. Nominal morphemes in Middle English (Lass 1992: 111)

Table 5 above shows noun paradigm in Middle English, which is an inheritance of the Old English period. Type A, on the one hand, is a modified continuation of the old masculine $a$-stems; while type $\mathrm{B}$, on the other, derives from the feminine $\bar{o}$-stems and certain weak $n$-stems (Lass 1992: 111).

As for the nouns appearing in W290, the singular paradigm selects either for - $\varnothing$ or for $-e$. The plural, on the contrary, shows a wider range of inflections:

\begin{tabular}{|c|c|c|}
\cline { 2 - 3 } \multicolumn{1}{c|}{} & Number of instances & $\%$ \\
\hline$-(e) s$ & 366 & 72.61 \\
\hline$-y s$ & 126 & 25 \\
\hline
\end{tabular}

14 According to van Gelderen (2006: 111), "this change occurs at different times in different parts of Britain: in the North and East, it proceeds faster than in the South and West, probably due to Scandinavian influence". 15 There are now [Middle English] two noun cases, genitive and 'common case'. Virtually all nouns have gone to the s-genitive and plurals, except for weak nouns that retain -en (Hogg and Denison 2006: 71). 


\begin{tabular}{|c|c|c|}
\cline { 2 - 3 } \multicolumn{1}{c|}{} & Number of instances & $\%$ \\
\hline$-i s$ & 4 & 0.79 \\
\hline$-n$ & 1 & 0.19 \\
\hline umlaut & 7 & 1.38 \\
\hline
\end{tabular}

Table 6. Plural morphemes in W290

As can be gathered from table 6 above, the preferred plural suffix in W290 was - $(e) s$, amounting up to 366 occurrences. The scribe also employed -ys quite frequently, although it only represents $25 \%$ of plural endings in the text. Endings like -is or $-n$, as well as umlaut plurals, rarely occurred.

\subsubsection{Personal pronouns}

The personal pronoun is the only word class that has consistently, throughout the history of language, maintained inflection, not only for number or the genitive, but also for other cases and gender as well (Lass 1992: 116; Hogg and Denison 2006: 72; van Gelderen 2006: 120).

\begin{tabular}{|c|c|c|c|}
\cline { 2 - 4 } \multicolumn{1}{c|}{} & Nominative & Objective & Genitive \\
\hline 1st sing. & I & me & - \\
\hline 2nd sing. & thou/thow/pou & - & - \\
\hline 3rd sing. & he & him/hym & - \\
\hline & she & - & - \\
\hline & it/yt/hyt & it/yt/hyt & - \\
\hline 1st plur. & we & - & - \\
\hline 2nd plur. & - & - & - \\
\hline 3rd plur. & thei/pei/pey & hem/them/pem & - \\
\hline
\end{tabular}

Table 7. Personal pronoun paradigm in W290.

Table 7 above reproduces the paradigm of pronouns in W290, which also represents the conventions of the Midlands dialect. As regards the third-person plural, it presents a mixed type, ${ }^{16}$ in which the nominative case makes use of the Scandinavian forms while the objective case still preserves the Anglo-Saxon variants (Mossé 1952: 55; Lass 1992: 120). ${ }^{17}$

16 According to Mossé, the forms of the third person plural pronoun can be of three types: 1) The native type (typical in the South, it employs the forms of Old English); 2) The Scandinavian type (present in the north of the country, it is characterized by Scandinavian th- forms); and 3) The mixed type (characteristic of the Midlands, combining forms of the two previous groups (1952: 55). This was more than probably due to the fact that, when it comes to Middle English, "almost everything new begins in the north and precolates down through the east Midlands. The southwest Midlands and the southeast remain the most conservative" (Hogg and Denison 2006: 71). 17 This [Scandinavian] system was not, however, borrowed all at once; it took at least 400 years for the new 
The third-person singular feminine also guides us specifically to the east midlands (Mossé 1952: 55-56; Brunner 1970: 59). Furthermore, Lass affirms that this preference for she is due to the fact that "for most of the Middle English period scho is restricted to the north, and sche to the east midlands, while the south keeps the old heo or its descendants (1992: 119).

\subsubsection{Verbs}

Verbs in Middle English are characterized by "some levelling of inflections and weakening of endings" (Baugh 1959: 194). By around 1300, the Old English System had been largely restructured everywhere, showing some dialectal variation (Lass 1992: 137):

\begin{tabular}{|l|c|c|c|c|c|}
\hline \multicolumn{2}{|c|}{ Present tense } & North & $\begin{array}{c}\text { West Mid- } \\
\text { lands }\end{array}$ & $\begin{array}{c}\text { East Mid- } \\
\text { lands }\end{array}$ & South \\
\hline \multirow{3}{*}{ Singular } & 1 & $-(\mathrm{e})$ & -e & -e & -e \\
\cline { 2 - 6 } & 2 & -es & -es(t) & -est & -est \\
\cline { 2 - 6 } & 3 & -es & -ep, -es & -ep, -es & -ep \\
\hline Plural & All & -es & -en, -es & -en, -es & -ep \\
\hline
\end{tabular}

Table 8. Dialectal distribution of verbal morphemes (present tense) (Lass 1992: 137)

Table 8 reproduces the present tense conjugation of verbs in the different dialects of Middle English. As can be observed, the first-person singular coincides in all the dialects, while the third-person singular together with the plural present a more varied paradigm.

\begin{tabular}{|c|c|c|}
\hline & Singular & Plural \\
\hline 1st person & $-\mathrm{e}$ & - \\
\hline 2nd person & -est, & - \\
\hline 3rd person & $\varnothing,-$ eth, -yth, -oth & $\varnothing,-e n,-y n$ \\
\hline
\end{tabular}

Table 9. Verbal morphemes (present tense) in W290

Table 9 above shows the morphemes for the present indicative appearing in W290. If the forms of third person singular are checked against table 8 , it could be safely stated that W290 was definitely copied following the conventions of the Midlands dialects. Furthermore, the second-person singular and the plural in $-n$ also point to that part of England.

paradigm to be established in the dialect complex that gave rise to the modern standards (Hogg and Denison 2006: 74-75). 
In view of the diversity in the forms for the third-person singular and the plural, the occurrences for each of their suffixes have been calculated to shed some light on the preferences of the scribe of W290. ${ }^{18}$

\begin{tabular}{|l|l|l|l|l|}
\cline { 2 - 5 } \multicolumn{1}{c|}{} & \multicolumn{4}{|c|}{ Occurrences $(\%)$} \\
\hline 3rd person singular & -yth (59,01) & -eth $(22,95)$ & -oth $(10,38)$ & $\varnothing(7,6)$ \\
\hline 3rd person plural & -en (74,19) & $\varnothing(19,35)$ & -yn $(6,45)$ & - \\
\hline
\end{tabular}

Table 10. Third-person morphemes (present tense) in W290

Table 10 shows the occurrences of third-person morphemes in W290. In the singular paradigm, $-y$ th and - eth $(59,01 \%$ and $22,95 \%$, respectively) stand out as the preferred forms, while -oth and $\varnothing(10,38 \%$ and $7,6 \%$, respectively) are seldom employed by the scribe. The plural paradigm, in turn, presents a clear preference for -en $(74,19 \%)$, followed by $-\varnothing$ and $-y n(19,35 \%$ and $6,45 \%$, respectively).

\section{CONCLUSIONS}

The present analysis suggests that W290 is likely to have been written in the south-eastern part of England, somewhere in the county of Essex. Using the LALME methodology, a questionnaire was implemented taking items from the general section of the atlas, but also including some items from the southern part of it. The findings in this stage of the analysis led us to propose the counties of Norfolk, Suffolk, Essex, London and Hertfordshire. Afterwards, the item maps of $L A L M E$ were employed with the intention of narrowing down that area. Another set of items was then plotted into zone 6 of the item maps (McIntosh et al. 1986), leading us to somewhere to the north of River Thames, near Chelmsford, in the county of Essex, thus following the conventions of the East Midlands dialect. The LP of W290 happens to be very similar to those of LP 6310 and LP 6350 in LALME (McIntosh et al. 1986), which also belong to that geographic area.

The objective of section 5 was to corroborate the findings in section 4 . Thus, some linguistic features of W290 were studied with the intention of linking them to specific areas of the country. For the purpose, the use of the graphs $\langle\mathrm{p}\rangle$ and $\langle\mathrm{y}\rangle$ has been studied together with the inflections of nouns, pronouns and verbs, where the results also leads us to the area corresponding to the Midlands.

18 Neither anomalous nor modal verbs have been included in the table. 


\section{REFERENCES}

Barber, J. C. BeAl and P. A. Shaw. 2009. The English Language: A Historical Introduction. Cambridge: Cambridge University Press.

BAUgh, A. and T. CABLE. 1959. A History of The English Language. London: Routledge.

Benskin, M. 1982. "The letters $<\mathrm{p}>$ and $<\mathrm{y}>$ in Later Middle English, and Some Related Matters". Journal of the Society of Archivists 7: 13-30.

1991. "The 'fit technique' explained". Regionalism in Late Medieval Manuscripts and Texts. Ed. Felicity RidDy. Cambridge: D. S. Brewer. 9-26.

Brown, M. 1990. A Guide to Western Historical Scripts from Antiquity to 1600. London: The British Library.

BrunNer, K. 1970. An Outline of Middle English Grammar. Oxford: Basil Blackwell.

Burrow, J. and T. Turville-Petre. 1996. A Book of Middle English. Oxford: Blackwell Publishers.

Calle-Martín, J. and A. Miranda-García. 2011. "From the manuscript to the screen: Implementing electronic editions of mediaeval handwritten material". Studia Anglica Posnaniensia 43.3: 3-20.

Calle-Martín, J. and D. Moreno-Olalla. 2008. "Body of Evidence: Middle English Annotated Corpora and Dialect Atlases". Studies in English Medieval Language and Literature, Volume 38: The Use and Development of Middle English: Proceedings of the Sixth International Conference on Middle English, Cambridge 2008. ED. RICHARD Dance and Laura Wright. Frankfurt and Main: Peter Lang. 17-34.

Crespo-García, B. and E. Lezcano-González. 1999. "A Preliminary Approach to Dialectal Localisation in Middle English”. Interpretations of English : Essays on Language, Linguistics and Philology. Ed. Isabel Moskowich-Spiegel FandiÑo. La Coruña: Universidad de la Coruña. 41-60.

Derolez, A. 2003. The Palaeography of Gothic Manuscript Books. From the Twelfth to the Early Sixteenth Century. Cambridge: Cambridge University Press.

Esteban-Segura,L. 2010. "Dialectal Study of a Version of the Middle English Gilbertus Anglicus: The Case of G. U. L. MS Hunter 509 (ff. 14r-167v)”. English Studies 91.3: 256-273.

FISIAK, J. 1983. "English Dialects in the Fifteenth Century: Some Observations Concerning the Shift of Isogloses". Folia Linguistica Historica 4.2: 195-217.

Hanna, R. 2005. London Literature, 1300-1380. Cambridge: Cambridge University Press.

Hogg, R. and D. Denison. 2006. A History of the English Language. Cambridge: Cambridge University Press. 
Jordan, R. 1974. Handbook of Middle English Grammar: Phonology. The Hague Paris: Mouton.

Kurath, H. et al., eds. 1956-2001. Middle English Dictionary. Ann Arbour: University of Michigan Press. [Electronic dictionary: <http://quod.lib.umich.edu/m/med/ lookup.html>]

LAING, M. 1988. "Dialectal analysis and Linguistically Composite Texts in Middle English”. Speculum 63: 83-103.

— 2004. "Multidimensionality: Time, Space and Stratigraphy in Historical Dialectology". Methods and Data in English Historical Dialectology. Ed. MARINA Dossena and Roger Lass. Bern: Peter Lang. 49-96.

Lass, R. 1992. "Phonology and Morphology". The Cambridge History of the English Language. Vol. 2, 1066-1476. Ed. Norman Blake. Cambridge: Cambridge University Press. 23-154.

1999. "Phonology and Morphology". The Cambridge History of the English Language. Vol. 3, 1476-1776. Ed. Roger Lass. Cambridge: Cambridge University Press. 56-186.

LEwIS, R. E. et al., eds. 1952-2001. Middle English Dictionary. Ann Arbor: University of Michigan Press. Online version in Middle English Compendium, edited by FRANCES McSparRAn. Ann Arbor: University of Michigan Press, 2000-. Available from http:// quod.lib.umich.edu/m/med/

McIntosh, A. 1989a. “The analysis of written Middle English”. Middle English Dialectology: Essays on Some Principles and Problems. Ed. Margaret Laing. Aberdeen: Aberdeen University Press. 1-21.

1989b. "A New Approach to Middle English Dialectology". Middle English Dialectology: Essays on Some Principles and Problems. Ed. Margaret Laing. Aberdeen: Aberdeen University Press. 22-31.

McIntosh, A., S.L. Samuels and M. Benskin. 1986. A Linguistic Atlas of Late Medieval English, 4 vols. Aberdeen: Aberdeen University Press.

Milroy, J. 1992. "Middle English Dialectology". The Cambridge History of the English Language. Vol. 2, 1066-1476. Ed. Norman Blake. Cambridge: Cambridge University Press. 156-206.

Miranda-García, A. and J. Garrido-Garrido. 2013. Text Search Engine. Málaga: University of Málaga.

Moorat, S. A. J. 1962. Catalogue of Western Manuscripts on Medicine and Science in the Wellcome Historical Medical Library Vol. I. Manuscripts Written Before 1650 $A D$. London: Publications of the Wellcome Historical Medical Library.

Moore, S., S. B. Meech and H. Whitehall. 1935. "Middle English Dialect Characteristics and Dialect Boundaries". Essays and Studies in English and Comparative 
Literature. Michigan: University of Michigan Publications in Language and Literature. 1-60.

Mossé, F. 1952. A Handbook of Middle English. Baltimore: The Johns Hopkins Press.

OAKDEn, J. P. 1930. Alliterative Poetry in Middle English: the Dialectal and Metrical Survey. Manchester: Manchester University Press.

Pahta, P. and I. TaAvitsainen. 2004. "Vernacularisation of Scientific and Medical Writing in its Sociohistorical Context". Medical and Scientific Writing in Late Medieval English. Ed. Irma Taavitsainen and Pärvi Pahta. Cambridge: Cambridge University Press. 1-22.

Parkes, M. B. 1969. English Cursive Book Hands, 1250-1500. London: Oxford University Press.

Petti, A. G. 1977. English Literary Hands from Chaucer to Dryden. Cambridge, Mass: Harvard University Press.

RoBerts, J. 2005. Guide to Scripts Used in English Writings up to 1500. London: the British Library.

Samuels, M. L. 1989. "Some Applications of Middle English Dialectology". Middle English Dialectology: Essays on Some Principles and Problems. Ed. Margaret LaING. Aberdeen: Aberdeen University Press. 64-80.

Simpson, J. A. and E. S. C. Weiner, eds. 1989. The Oxford English Dictionary on CDROM. 2nd Edition. Oxford: Oxford University Press.

Sмiтн, J. J. 1999. Essentials of Early English. London: Routledge.

Тацвот, С. H. 1967. Medicine in Medieval England. London: Oldbourne.

The Málaga Corpus of Late Middle English Scientific Prose. 2013. http://hunter.uma.es.

VAn Gelderen, E. 2006. A History of the English Language. Amsterdam: John Benjamins Publishing Company. 
